\author{
${ }^{1}$ Pomfret, Richard, \\ ${ }^{1} \mathrm{PhD}$, professor The University of Adelaide, Adelaide, Australia \\ e-mail: pompid@gmail.com
}

\title{
REGULATION OF THE DIGITAL ECONOMY
}

\begin{abstract}
The digital economy is becoming an important driver of innovation, economic growth and competitiveness. More than 15 countries are implementing a national programme of digitization. The formation and development of the national segment of the digital economy through the use of trusted, mainly domestic ICT, and its further integration into the global digital economy, on the one hand, provides a "window of opportunity" for the integration of the economy of the Republic of Kazakhstan in the emerging world economic order, and on the other hand - carries significant risks to economic security and sovereignty of the state. The purpose of the study is to analyze the current state and develop effective measures to regulate the digital economy to achieve sustainable economic growth, improve the competitiveness of the economy and improve the quality of life of the population of the Republic of Kazakhstan. The introduction of information technologies in the public sector brings to a qualitatively new level key aspects of life - from payment for utilities to insurance policies and treatment. The methodology is based on methods of analysis, synthesis, induction and deduction. The value of the research is that the model of digital economy development is defined. The practical significance of the study lies in the development of proposals to improve the regulation of the digital economy in the Republic of Kazakhstan.

Key words: digital economy, digital dividends, digital state, single digital market, online sales, development of electronic networks and digital services.
\end{abstract}

Introduction. The rapid decline in computing costs, the emergence of the Internet as a communication tool, the rapid development of the mobile internet, the proliferation of day-to-day applications, and the increasing role of internetbased social networks and commercial platforms, have greatly affected the functioning of the economy and have profoundly affected businesses, public organisations, and personal life.

Emerging digital technologies such as the Internet of Things, artificial intelligence, and Big Data, will lead to further disruptive innovation, and create new opportunities and challenges.

Digitalisation has brought many benefits to consumers and businesses, but it has also generated new problems and policy issues. Policy makers are struggling to respond to these new challenges.

AI Watch will monitor and assess European AI landscapes from driving forces to technology developments, from research to market, from data ecosystems to applications.

AI Watch will monitor the implementation of the Coordinated Plan including strategies and investment.

From these in-depth analyses, we will be able to understand better Europe's areas of strength and areas where investment is needed to boost AI in in Europe.
AI has a wide range of potential economic and social implications including new forms of economy and governance. AI Watch will provide an independent assessment of the impacts and benefits of AI on growth, jobs, education, and society.

Digitalisation makes information and knowledge easy to store, access and modify. Digital technologies create a media and communications system that increasingly links all parts of social and economic life.

This, and the interactivity between the user and the content, facilitates the proliferation of creative re-combinations of knowledge and technologies.

The JRC is investigating the processes in which digital innovation and entrepreneurial activity take place and what framework conditions facilitate them, including the role of Intellectual Property Rights and standardisation of complex and interdependent technologies.

Sharing information on environmental and social phenomena is at the heart of Digital Economy. To do so we need a framework of technologies, standards, organisational arrangements and policies that makes it possible to find, access, use, share, and publish such information, in other words we need an information infrastructure, or to be more precise we need to connect the multiple information infrastructures being developed across the world. 
In modern economic conditions in many countries, the digitalization of the economy is a strategic priority of development. According to the forecasts of the world's leading experts, by 2020 a quarter of the world economy will be digital, and the introduction of technologies of digitalization of the economy, allowing the state, business and society to interact effectively, is becoming an increasingly large-scale and dynamic process (Digital Kazakhstan, 2018). Singapore forms the "Smart economy", Canada creates an ICT-hub in Toronto, South Korea in the "Creative economy" focuses on the development of human capital, entrepreneurship and the spread of ICT, while Denmark focuses on the digitalization of the public sector.

Currently, the attention of the Government of the Republic of Kazakhstan and society to digitalization as a global trend, including the expectations of the socio-economic effect of their implementation, are significant. And this level, first of all, is set by the scale and specifics adopted by the President of Kazakhstan N. Ah. Nazarbayev plan of the nation "100 concrete steps" (plan of the Nation -100 concrete steps).

In particular, one of the" 100 steps "is the creation of the state Corporation" Government for citizens "- a single provider of public services on the model of Canada Service in Canada and Centrelink in Australia (National Plan -100 concrete steps).

As part of the current reforms, Kazakhstan is focused on countries that have achieved significant success in creating a digital state. As you know, it is Austria, USA, Denmark, Australia, Canada, Singapore. According to the level of digitalization of the economy in 2016, Kazakhstan took the 50th place in the ranking of 85 countries and was in the group with the emerging digital economy (Third modernization: global competitiveness, 2017).

In the message of the President of the Republic of Kazakhstan to the people of Kazakhstan "the Third modernization of Kazakhstan: global competitiveness" dated January 31, 2017, it is noted that it is necessary to develop in the country such promising industries as $3 \mathrm{D}$ printing, online trading, mobile banking, digital services, including health and education, and others. These industries have already changed the structure of the economy of developed countries and gave a new quality to traditional industries (Tulegenova M. S., Syzdyk N. S. 2017, 12).

In connection with these aspects, The state program "Digital Kazakhstan" was developed (Digital Kazakhstan, 2017). The basis for its development was the decree Of the President of the Republic of Kazakhstan dated February 1, 2010 № 922 "on the Strategic development plan of the Republic of Kazakhstan until 2020" (on the strategic development plan of the Republic of Kazakhstan, 2010).

The Foundation of the program "Digital Kazakhstan" was the state program "Information Kazakhstan-2020", approved in 2013 (Information Kazakhstan-2020). In The Message Of The President Of Kazakhstan N. Ah. Nazarbayev "growth of welfare of Kazakhs: increase of income and quality of life" from October 5, 2018.it is noted that it is necessary to ensure the development of such areas of the "economy of the future" as alternative energy, new materials, Biomedicine, big data Internet of things, artificial intelligence, blockchain and others. The place and role of the country in the global world depend on them in the future (growth of welfare of Kazakhstan Citizens: increase of income and quality of life, 2018). The world Bank names three important categories of problems that are signs of the possibility of digital transformation: legal regulation, the availability of skills in the population and the creation of appropriate institutions of digital governance (the Digital economy has transformed, transformed 2018). Therefore, in order to transform the economy into a digital one, it is necessary to create an appropriate regulatory framework for e-business, reform the education system and involve citizens in the management of the state through e-services, transparency and control over budget spending. Such well-known foreign scientists as: M. Bahl, D. Charoen, C. Granasambandam, M. Knickrehm, R. Kling, K. Lamb, L. Margherio, L. Lane, T.L. Mesenbourg, M. Rouse, A. Tapscot.

Literature review. Research of the main trends of the digital economy dedicated to the works by I. V. Alekseeva, A. S. Airapetian, A. Bryan, A. P., Dobrynin, A. V. Druzhinin, K. A. Zhumagaliev, V. Ivanov, V. Yu. Konyukhov, D. Marchukova, V. P. Kuprianov, I. A. Matveeva, E. V. Popova, K. A. Seed, N.. Stefanova, D. V. Sikorski, D. A. Smirnova, I. M. Tushkanova, A. Rusina, L. Yu., Chernykh, A. A. Kharchenko and T. N. Yudina.

In the Republic of Kazakhstan, the problem of formation and development of the digital economy, Internet marketing, the information sector of the economy were engaged in such scientists as A. A. Ashimov, Dnishev F. M., A. K. Koshanov, G. M. Mutanov, B. M. Mukhamediev, N. To. Theoretical and practical issues], K. A. Sagadiyev, M. S. Tulegenova A. G., and Ploshay.

Despite the scientific contribution of scientists to the theory and practice of the formation and 
development of the digital economy, there are issues that require further study, in particular, requires clarification of the regulation of the digital economy.

The relevance, great demand, and not the study of the main trends in the development of the digital economy in the future predetermined the choice of topics and main areas of research.

Material and Methods. The research methodology is based on a comprehensive analysis of the problem. The state can provide a "digital leap" in the country through the accelerated development of specific technologies. In such cases, the state assumes the role of an investor, determining the key, the most promising areas of financing, based on the assessment of long-term return on investment, competitive position, trends, as well as invested in the fundamental conditions of success, such as education and retraining. In South Korea, with the active position of the state, support companies are beginning to independently invest in breakthrough digital technologies.

Thus, one of the largest Telecom operators in the country-SKT - has indicated its intention to invest more than 4 billion US dollars in artificial intelligence and Internet of things technologies. Table 1 shows what tasks and goals should be set by the state and companies in order to achieve good results in the implementation of digitalization in the country (Tabl. 1):

Table 1 - Challenges faced by the state and companies for the introduction of the digital economy in Kazakhstan*

\begin{tabular}{|c|c|}
\hline Companies & State \\
\hline $\begin{array}{c}\text { Introduction of new technologies, improvement } \\
\text { and digitalization of production processes }\end{array}$ & Improvement and digitalization of production processes \\
\hline $\begin{array}{c}\text { Search for new personnel, cooperation } \\
\text { with educational and research centers }\end{array}$ & $\begin{array}{c}\text { Introduction of new approaches to learning, improvement } \\
\text { of educational processes }\end{array}$ \\
\hline $\begin{array}{c}\text { Investment in new technologies, choice } \\
\text { of advanced areas }\end{array}$ & $\begin{array}{c}\text { Increasing investment in NIOC } \\
\text { due to the disappearance of many professions and } \\
\text { the emergence of new professions and jobs }\end{array}$ \\
\hline $\begin{array}{c}\text { Increase of competitiveness, development } \\
\text { of innovative culture on the model of the } \\
\text { world's highly developed digital companies }\end{array}$ & $\begin{array}{c}\text { Improvement of the innovation processes and } \\
\text { good management on the part of the state. } \\
\text { Digitalization of public services, increasing literacy } \\
\text { and universal involvement of the population in the } \\
\text { digital economy }\end{array}$ \\
\hline \multicolumn{2}{|c|}{$*$ Note: developed by the author } \\
\hline
\end{tabular}

The digital economy in developed countries develops in different ways, but they have important common features: an enabling environment for development and innovation, as well as large investments in digital technology and infrastructure. Kazakhstan has great opportunities to make technological leaps in all sectors of the economy. For the successful functioning of the digital economy in the country is necessary: the development of infrastructure with Internet access, using telecommunications, as well as e-business and Commerce. In accordance with the main directions of administrative reform, the priorities of the use of information technology in public administration are:

1) improving the effectiveness of the implementation of the law establishing the functions of the state and improving the mechanisms of state regulation.

2) improving the efficiency of law enforcement activities of public authorities.

3 ) improving the efficiency of control and Supervisory functions (Stefanova N. A, 2018 -122).

The legal framework for the regulation of the Kazakhstan market should take better account of the specifics of the relations developing in it. Therefore, it is important to take into account in the legislative form the degree and form of assistance of state employment agencies, both participants in the labor market: the employer and the unemployed. In this regard, it is effective, first of all, to provide financial support to entrepreneurs who create additional jobs for the unemployed, through the 
competent employment authorities. The need for the regulatory role of the state in restructuring the social development of organizations, taking into account the growing tension in the domestic labor markets, becomes obvious, which is confirmed by the special attention of the state to solving social problems.

In this regard, we believe that it should:

- develop a strategy for regulating the digital economy in accordance with the chosen model of development of the Republic of Kazakhstan and its regional features;

- develop a package of legislative acts, providing them with temporary housing and health services, social insurance.

Research result. The greatest difficulty is the issue of regulation of innovative processes is the fact that technology is evolving faster than the legislation. The Law "on digital economy in the Republic of Kazakhstan" is proposed (figure 1). Solutions can have a counter - effect: for example, increased control over information can affect the development of the Internet, and support for a particular format of digital communications-lead to the consolidation of one business model, while creating obstacles to the emergence of new ones.

Results and Discussion. Strengthening the system of state control over the procedures of the digital economy involves monitoring for possible insolvency of the activities of not only economically and socially important enterprises. We consider it necessary to expand the coverage of enterprises. In addition, the implementation of state control and monitoring should cover more extensive crisis management infrastructure. The formation of the development model is the key to sustainable development of the company. To understand the structure of the classical economic model, it is necessary to consider the main subjects and mechanisms of economic interaction (Fig. 1):

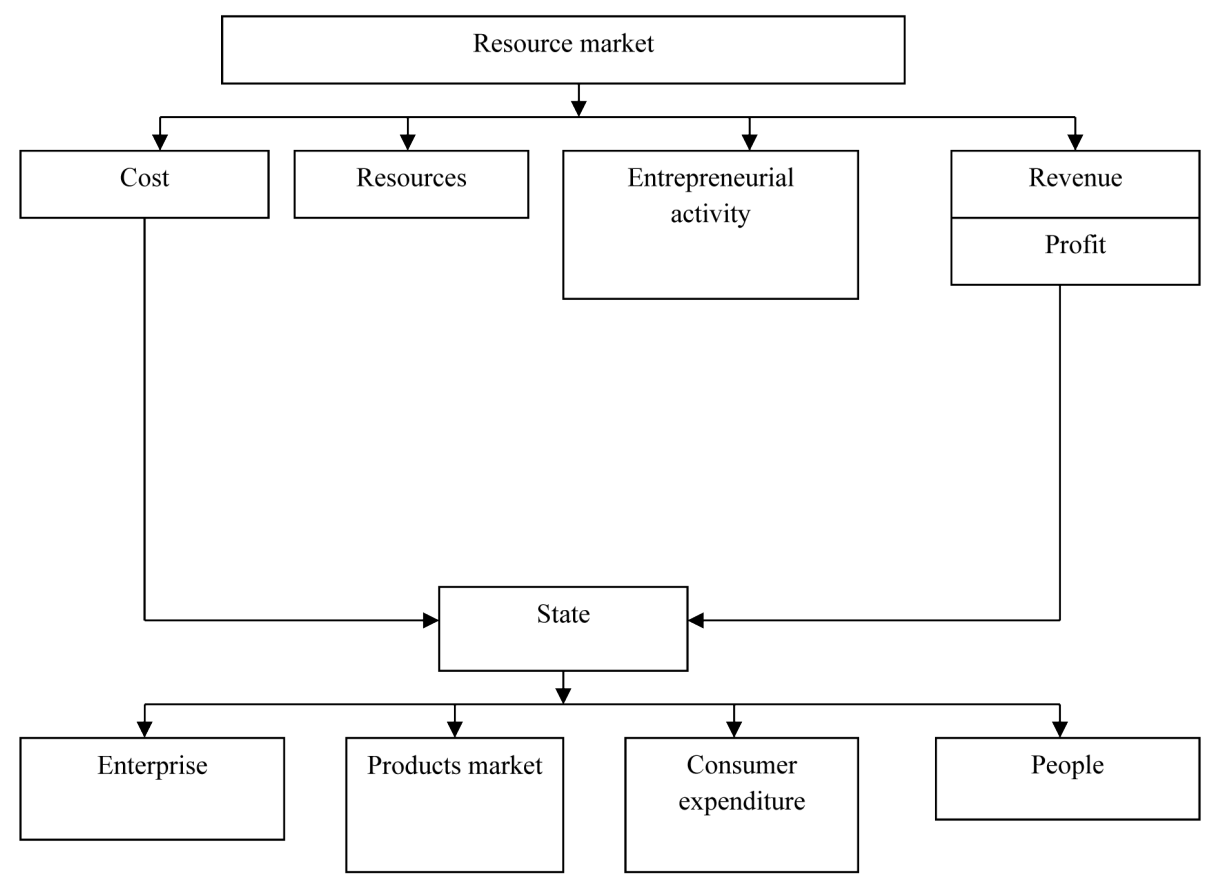

Figure 1. Economic model

*Note: according to literature 2, 3

In the national economy there are three entities: the population (households), enterprises, and the state. Each of the economic entities under consideration has a number of specific features that carry out many activities. The main creative element of economic turnover are enterprises (firms) that produce the necessary products and services for society (households). The activities of firms aimed at making a profit. For the products sold, firms receive an appropriate monetary equivalent, in addition, they are the state's preddacha consists in the production of public goods, i.e. goods that are produced in the 
interests of the whole society. These include security, social protection, the development of science and culture, and the formation of social infrastructure. The activity of the state does not pursue the purpose of profit and is aimed at the realization of national interests. Most authors who write about the economic model try to compare it with the economic models of other countries, the same level of development in different ways and methods (in the competitiveness index Kazakhstan took 59th place, 2018).

The digital economy is characterized by many indicators, in particular the index of economic freedom is calculated on the average of ten benchmarks: property rights, freedom from corruption, fiscal freedom, government participation, freedom of enterprise, labor, trade, investment, monetary freedom, and financial freedom. In terms of the index, the Republic of Kazakhstan ranks 153rd out of 178 possible places from the countries represented in the ranking by methods (in the competitiveness index Kazakhstan took 59th place, 2018). In countries with freer economies, the welfare of the population is much higher, with economic freedom yielding relatively quick and tangible results, in contrast to the total state regulation of the economy, which prevails (Ranking of the world's countries by the level of economic freedom, 2017). Countries that pursue policies of economic freedom create favorable conditions for trade, entrepreneurship and innovation that generate economic growth. The index of economic freedom is primarily based on the degree of economic liberalism, covering macroeconomic indicators such as growth rates, degree of technological modernization, the level of development of infrastructure and that it innovation is important.

The conclusions emphasize the importance of the state of economic freedom, and therefore the economic model as a whole for the population. In" free " countries, it innovations are also more developed. Such countries have higher national income (the most developed countries in the field of IT technologies are Named, 2018). The policy of economic freedom creates favorable conditions for the development of the it industry, which is considered to be the fastest growing industry in many countries of the world (Top 10 countries with advanced technologies, 2018). Thanks to digital telecommunications, which include modern digital innovations, a model of the digital economy is often called the digital future (nnemtsov, 2017-320). The analysis of the economic situation, the rating of economic freedom, in the lists of which is not the best result, showed that the economy of the Republic of Kazakhstan must move from the existing model, which is used to the population, to the new digital economy of the future. Thus, the model of development of the digital economy should be implemented through digital telecommunications, which include modern innovations such as cloud computing, business Analytics, big data and much more. The main resource of the digital economy is information that does not dry up like other types of resources, it can be used an infinite number of times. The Internet is a global global network in which the area of use of resources is not limited, as well as storage thanks to cloud technologies. Today, all companies strive for digital trends, thanks to which there is a profit. And digital trends, in turn, contribute to the simplification of the population's life, and improve the state of the economy in the country. Currently, the desire of transition to a digital economy has engulfed all spheres of life: education, online sales, health care, etc. For example, create server public services, made a significant step forward for simplification of life of the population. The accumulation of a large amount of information on the Internet has led to the need to store it somewhere and this has contributed to the emergence of new technologies such as big data and business Analytics. Big data or big data is applicable in many areas such as medicine and even in the field of education, where the need to store a large amount of information is at the forefront. Business Analytics, in turn, is applicable in any areas where the company is faced with a constant flow of business information. These areas are one of the key drivers of information technology development. Thus, the presented model of development of the digital economy orients the company in accordance with the goals for effective work both in the short and long term. In this model, the main attention is paid to the adaptive response to the emergence of possible adverse situations. The very appearance of these situations is predicted, and measures to neutralize them are developed in advance. The application of this model of development of the digital economy will enhance the quality of ongoing monitoring of the market, the performance of planning of its development and the effectiveness of regulatory measures.

Conclusion.The essence of the digital economy lies in the fact that thanks to the development of digital technologies, the consumer can quickly get the services he needs, save money by buying products in online stores at lower prices. The core of the digital economy is the digital goods and services sector.

The growing role of the digital economy is that the digital economy is the basis of development in 
General and has an impact on a variety of industries such as banking, retail, transport, energy, education, health and many others. Currently, a number of factors affecting the development of the digital economy can be identified. Internal factors are managerial. External factors - infrastructure and General economic.

For the growth of the digital economy it is necessary to develop the national it sector, to stimulate the creation of innovative technologies, to cooperate with foreign market actors for their development. It is necessary to attract investment and motivation of entrepreneurial activity in this
industry.All strata of society - the state, the private sector, civil society and the it community-must participate in digital economic activities. Ensuring information security of information and innovative technologies is also an important component.

The regulation of the digital economy needs to be improved. The greatest difficulty is the issue of regulation of innovative processes is the fact that technology is evolving faster than industrial relations. At the same time, a draft Law "on the development of the digital economy in the Republic of Kazakhstan"is proposed.

\section{References}

Digital Kazakhstan: realities and prospects. [Electronic resource.] Mode of access: https://primeminister.kz/ru/news/all/tsifrovoikazahstan-realii-i-perspektivi-16155.Дата treatment 10.03.2018.

Decree Of the President of the Republic of Kazakhstan № 922 “on the Strategic development plan of the Republic of Kazakhstan until 2020" dated February 1, 2010

Kazakhstan ranked 59th in the competitiveness index. [Electronic resource.] Access mode: https://24.kz/ru/news/economyc/ item/271998-v-indekse konkurentosposobnosti kazakhstan-zanyal-59-mesto. Date of application: 17.10.2018

Named the most developed countries in the field of It [electronic resource]. Mode of access: https://www.kommersant.ru/ doc/998722.Дата treatment: 29.10.2018

Nemtsov, A. K., the Russians waiting for the digital economy. High technology can revive a weak economy.- M.: $2017-320$ p.

National Plan-100 concrete steps to implement the five institutional reforms of the Head of state Nursultan Nazarbayev from 05.2015 .

National action plan for the implementation of The President's Address to the people of Kazakhstan "Third modernization of Kazakhstan: global competitiveness" dated January 31, 2017.

Stefanova N. (2018) Evaluation of the digital economy//Vestnik of the Volga state University of telecommunications and Informatics. - № 11. - P. 122-124.

State program "Digital Kazakhstan”. Approved by the government of Kazakhstan № 827, from 12.12. 2017.

State program "Information Kazakhstan-2020". As amended on 19 March 2010

The welfare of the Kazakh dance: increase incomes and quality of life. Message Of The President Of The Republic Of Kazakhstan N. Nazarbayev to the people of Kazakhstan from 5 October 2018.

The Digital economy has been transformed. [Electronic resource.] Mode of access: http:/www.connect-wit.ru/tsifrovaya-ekonomika-transformirovalas-transformirovalas.html. Date of access 1.04.2018.

Top 10 countries with advanced it Technologies. [Electronic resource.] Mode of access: https://www.vestifinance.ru/articles/73084. Date of access: 10.07.2017.

Tulegenova M. S., Syzdyk N. With. The digital economy and new directions of social development of Kazakhstan // Bulletin of the University of Turan. - 2017 - №4. - Pp. 12-131.

World ranking on the level of economic freedom according to HeritageFoundation [Electronic resource]. Mode of access: http:// gtmarket.ru/ratings/index-of-economic-freedom. Date of access: 20.12.2017 